\title{
RELIABILITY, RESPONSIVENESS, DAN EMPHATY TERHADAP KEPUASAN KONSUMEN MALL PELAYANAN PUBLIK DI KABUPATEN SUMENEP
}

\author{
Nur Qoudri Wijaya ${ }^{1}$ \\ Ahmad Ghufrony ${ }^{2}$ \\ Raudatunnisah $^{3}$ \\ ${ }^{1}$ Universitas Wiraraja, Indonesia \\ nurqoudri@wiraraja.ac.id, \\ ${ }^{2}$ Universitas Wiraraja, Indonesia \\ ghufrony@wiraraja.ac.id \\ ${ }^{3}$ Universitas Wiraraja, Indonesia \\ anis_imuts55@yahoo.com
}

\begin{abstract}
The problem examined in this thesis is that there are problems that need to be repaired and improved such as the building used does not cover the number of companies in it so that on certain days many consumers still lack seats in the waiting room, as for another thing, the parking spae provided is not very wide so disturbing the public facilities in the parking area of the town square of Sumenep. Therefore, to find out more about the service quality of public service Malls in Sumenep district, the researchers conducted research with the title of service quality (Reliability (X1), Responsiveness (X2), and Emphaty (X3) ) on consumer satisfaction in Public Service Mall in Sumenep Regency. In answering these problems, researches used purposive sampling method, namely the method of determining the sample with certain considerations. The results of the researcher show that the variables of Reliability (X1), Responsiveness (X2), and Emphaty (X3) have a significant effect on customer satisfaction in order to improve the quality of service and the comfort of the community while at the Public service Mall in Sumenep Regency.
\end{abstract}

Keywords : service quality ( Reliability, Responsiveness and Emphaty) on customer satisfaction.

\section{PENDAHULUAN}

\section{Good}

\section{Governance}

adalah

mendekatkan

pemerintah

dengan

rakyatnya.

Pentingnya

Good

Governance ini dapat menciptakan atau dapat membuat pemerintah dekat dengan rakyat sehingga pemerintah dapat mengetahui kebutuhan dan permasalahan yang ada dimasyarakat sehingga kebutuhan masyarakat dapat terpenuhi atau dilayani oleh pemerintah.
Good Governance perlu di terapkan terhadap pelaksanaan pelayanan publik karena awal mulanya konsep ini ada dikarenakan kurang baiknya kinerja ASN dalam melayani masyarakat. Sehingga dengan cara seperti ini bisa memberikan pelayanan yang diharapkan masyarakat. Good Governance dikaitkan dengan bagaimana pemerintah mengelola suatu pemerintahan yang bersinergi dengan masyarakat dan dunia usaha sehingga pengelolaan 
pemerintahan berjalan dengan bersih, demokratis, dan efektif yang selaras dengan undang - undang 1945 yaitu menjadikan masyarakat makmur, sejahtera dan mandiri

Konsep Good Governance memberikan masukan kepada pemerintah baik di pusat maupun di daerah tentang pandangan dalam memberikan pelayanan yang baik bagi masyarakat. Dalam rangka menciptakan Good Governance diperlukan adanya pelayanan yang prima dimana kepuasan konsumen/masyarakat yang menjadi tujuan utama. Sebab jika memberikan pelayanan yang baik atau pelayanan yang memenuhi standar maka konsumen dapat merasakan kepuasan atas pelayanan yang dilakukan di mall pelayanan publik.

Pemerintah Kabupaten Sumenep kini telah memiliki mall pelayanan publik (MPP), dimana mall pelayanan publik tersebut digunakan sebagai tempat pelayanan semua instansi. Pada dasarnya pelayanan merupakan bentuk kegiatan yang dialakukan sesorang dalam melayani konsumen . Sedangkan Publik sendiri yaitu mengenai orang atau masyarakat, yang berhubungan dengan bangsa, negara, atau komunitas. Mall pelayanan publik atau yang disingkat MPP diselenggarakan oleh organisasi perangkat daerah dan ditempatkan pada gedung khusus guna melaksanakan tugas dan fungsi di bidang penanaman modal dan pelayanan terpadu satu pintu.

Setiap Mall Pelayanan Publik mempunyai kualitas pelayanan sendiri, begitupula pada Mall Pelayanan Publik yang ada di kabupaten sumenep ini yang juga mempunyai kualitas pelayanan. Kualitas pelayanan public merupakan layanan yang diberikan oleh pemerintah pusat, pemerintah daerah maupun BUMN dan BUMD. Masing - masing Dinas dan perusahaan memberikan pelayanan kepada masyarakat dan konsumen sehingga mereka merasakan manfaat dengan adanya pelayanan public.

Keberhasilan mendirikan mall pelayanan publik ini ditentukan oleh bagaimana perusahaan yang ada di dalam mal pelayanan publik tersebut memberikan pelayanan yang diberikaan terhadap konsumen. Kualitas pelayanan yang diberikan di mall pelayanan public bertujuan untuk memudahkan masyakat atau konsumen mendapatkan kemudahan pelayanan yang diberikan oleh pemerintah

Di kabupaten Sumenep terdapat mall pelayanan publik yang di dalamnya terdapat 13 dinas atau perusahaan diantaranya : Disdukcapil, Pu. Prkp \& Cipta Karya, Pu. Sumber Daya Air, Pu. Bima Marga, Dinas Lingkungan Hidup, Dinas Kesehatan, BPPKAD, PDAM, Bpjs Kesehatan, Bpjs Ketenagakerjaan, 
Kantor Pelayanan Pajak, Kantor Samsat,

Dinas Perhubungan, Dinas Tenaga

Kerja, BKPSDM, Bank Jatim. Dimana semua dinas atau perusahaan mendaftarkan perusahaannya ke dalam mall pelayanan publik meminta surat izin terhadap dinas perizinan terlebih dahulu bisa juga dikatakan bahwa dinas atau perusahaan yang ada di dalam mall pelayanan publik dibawah naungan dinas perizinan, baru setelah itu dinas perizinan melakukan perundingan dengan pemerintah kabupaten yang nantinya pemerintah kabupaten akan memberikan dana ke perusahaan atau dinas yang akan mendaftarkan sebagai perusahaan atau dinas yang akan menyediakan pelayanan di mall pelayanan publik tersebut.

Mall pelayanan publik di kabupaten sumenep merupakan mall yang didirikan oleh pemerintah Kabupaten Sumenep pada tahun 2019 yang baru-baru ini mall pelayanan publik di dirikan oleh Pemerintah Kabupaten Sumenep dimana mall pelayanan publik itu dipusatkan di gedung nasional indonesia (GNI), disebelah timur alun-alun Kota Sumenep. Dimana pemerintah mengharapkan agar dinas atau perusahaan yang tergabung di dalamnya dapat mampu membangun konektivitas antar instansi untuk memberikan kecepatan layanan, bahkan pelayanannya tidak hanya sampai jam kantor, namun hingga malam hari.

Sistem pelayanan berakibat pada kepuasan konsumen yang dirasakan seperti pada halnya di mall pelayanan publik kabupaten sumenep dimana masih ada beberapa masalah yang perlu diperbaiki dan ditingkatkan seperti gedung yang digunakan kurang mencakup jumlah perusahaan yag ada didalamnya sehingga pada hari tertentu banyak konsumen yang masih kekurangan tempat duduk diruang tunggu, adapun hal lainnya adalah tempat parkir yang disediakan tidak terlalu luas sehingga mengganggu pada fasilitas umum pada area parkir alunalun Kota Sumenep

\section{METODE PENELITIAN}

Penelitian ini menggunakan metode penelitian kuantitatif dengan mencari pengaruh antara variable independent terhadap variable dependen. Penelitian di lakukan di Mall Pelayanan Publik di Kabupaten Sumenep sebelah timur alunalun kota sumenep di Gedung Nasional Indonesia (GNI). Dalam penelitian ini populasinya adalah seluruh konsumen Mal Pelayanan Publik yang jumlahnya tidak diketahui secara pasti. Teknik pengambilan sample non probability sampling yang dibagi menjadi enam, peneliti memfokuskan lagi dengan menggunakan atau pengambilan sampel menggunakan metode Purposive 
sampling. Jumlah sampel penelitian ini adalah 80 orang. Sampel dari penelitian ini adalah konsumen Mall Pelayanan Publik di Kabupaten Sumenep.

Penulis menggunakan data subjek (self- report data). Yaitu penelitian berupa kualitas pelayanan terhadap kepuasan konsumen di Mall Pelayanan Publik di Kabupaten Sumenep. Dalam penelitian ini dilakukan dengan memberikan kuisioner langsung pada responden Mall Pelayanan Publik di Kabupaten Sumenep. Data sekunder di dapat dari literatur maupun dari penelitian terdahulu.

Data dianalisis dengan menggunakan Uji Kualitas Instrumen Uji Validitas Uji Reliabilitas Uji Asumsi Klasik (Uji Linieritas, Uji Normalitas, Uji Heteroskedastisitas), Regresi Linier Berganda, Uji Parsial ( $\mathrm{Uji} \mathrm{t}$ ), Uji Simultan (Uji F ), Uji Determinasi $\left(\mathrm{R}^{2}\right)$.
Semua analisis menggunakan software SPSS yang kemudian di sajikan dalam bentuk tabel, gambar dan deskripsi.

\section{HASIL PENELITIAN}

Supaya dalam pengujian berjalan yang sesuai diharapkan, sebelum analisis data dilakukan pengujian data berupa uji validitas dan uji reliabilitas.

\section{Uji Validitas}

Adapun hasil uji validitas kuesioner variabel reliability yang diteliti disajikan pada tabel 1.

Hasil uji validitas kuesioner variabel responsiveness yang diteliti disajikan pada tabel 2 .

Hasil uji validitas kuesioner variabel emphaty yang diteliti disajikan pada tabel 3 .

Hasil uji validitas kuesioner variabel Kepuasan Konsumen yang diteliti disajikan pada tabel 4 .

Tabel 1

Hasil Uji Validitas Variabel Reliability $\left(\mathrm{X}_{1}\right)$

\begin{tabular}{|c|c|c|c|}
\hline Butir Pernyataan & $\mathbf{r}_{\text {hitung }}$ & Titik Kritis & Keterangan \\
\hline Pernyataan 1 & 0,930 & 0,30 & Valid \\
\hline Pernyataan 2 & 0,920 & 0,30 & Valid \\
\hline Pernyataan 3 & 0,949 & 0,30 & Valid \\
\hline Pernyataan 4 & 0,920 & 0,30 & Valid \\
\hline Pernyataan 5 & 0,901 & 0,30 & Valid \\
\hline Pernyataan 6 & 0,901 & 0,30 & Valid \\
\hline
\end{tabular}

Sumber : Hasil Pengolahan Data 2020

Tabel 4.2

Hasil Uji Validitas Variabel Responsiveness $\left(\mathrm{X}_{2}\right)$

\begin{tabular}{|c|c|c|c|}
\hline Butir Pernyataan & $\mathbf{r}_{\text {hitung }}$ & Titik Kritis & Keterangan \\
\hline Pernyataan 1 & 0,987 & 0,30 & Valid \\
\hline Pernyataan 2 & 0,981 & 0,30 & Valid \\
\hline Pernyataan 3 & 0,982 & 0,30 & Valid \\
\hline Pernyataan 4 & 0,937 & 0,30 & Valid \\
\hline
\end{tabular}

Sumber : Hasil Pengolahan Data 2020 
Tabel 3

Hasil Uji Validitas Variabel Emphaty $\left(\mathrm{X}_{3}\right)$

\begin{tabular}{|c|c|c|c|}
\hline Butir Pernyataan & $\mathbf{r}_{\text {hitung }}$ & Titik Kritis & Keterangan \\
\hline Pernyataan 1 & 0,950 & 0,30 & Valid \\
\hline Pernyataan 2 & 0,951 & 0,30 & Valid \\
\hline Pernyataan 3 & 0,943 & 0,30 & Valid \\
\hline
\end{tabular}

Sumber : Hasil Pengolahan Data 2020

Tabel 4.4

Hasil Uji Validitas Variabel Kepuasan Konsumen (Y)

\begin{tabular}{|c|c|c|c|}
\hline Butir Pernyataan & $\mathbf{r}_{\text {hitung }}$ & Titik Kritis & Keterangan \\
\hline Pernyataan 1 & 0,888 & 0,30 & Valid \\
\hline Pernyataan 2 & 0,909 & 0,30 & Valid \\
\hline Pernyataan 3 & 0,919 & 0,30 & Valid \\
\hline Pernyataan 4 & 0,819 & 0,30 & Valid \\
\hline Pernyataan 5 & 0,893 & 0,30 & Valid \\
\hline Pernyataan 6 & 0,883 & 0,30 & Valid \\
\hline Pernyataan 7 & 0,842 & 0,30 & Valid \\
\hline Pernyataan 8 & 0,800 & 0,30 & Valid \\
\hline
\end{tabular}

Sumber : Hasil Pengolahan Data 2020

Pada tabel 1 diatas disimpulkan

bahwa butir pertanyaan layak digunakan untuk dilanjutkan analisis

Pada tabel 2 diatas disimpulkan bahwa butir pertanyaan layak digunakan untuk dilanjutkan analisis

Pada tabel 3 diatas disimpulkan bahwa butir pertanyaan layak digunakan untuk dilanjutkan analisis.
Hasil uji validitas kuesioner variabel Kepuasan Konsumen yang diteliti disajikan pada tabel 4 .

Dari tabel diatas disimpulkan bahwa butir pertanyaan layak digunakan untuk dilanjutkan analisis

\section{a. Uji Reliabilitas}

Hasil dari uji reliabilitas berdasarkan pada rumus alpha cronbach diperoleh hasil sebagai berikut:

Tabel 5

Hasil Uji Reliabilitas Kuesioner Penelitian

\begin{tabular}{|c|c|c|c|}
\hline Variabel & $\begin{array}{c}\text { Koefisien } \\
\text { Reliabilitas }\end{array}$ & Nilai Kritis & Keterangan \\
\hline Reliability & 0,963 & 0,6 & Reliabel \\
\hline Responsiveness & 0,980 & 0,6 & Reliabel \\
\hline Emphaty & 0,943 & 0,6 & Reliabel \\
\hline Kepuasan Konsumen & 0,953 & 0,6 & Reliabel \\
\hline
\end{tabular}

Sumber : Hasil Pengolahan Data 2020 
Tabel 6

Jawaban Responden Pernyataan Pada Variabel

\begin{tabular}{|c|c|c|c|c|c|c|}
\hline \multirow{2}{*}{ No. } & \multicolumn{7}{|c|}{ Jawaban Responden } & \multirow{2}{*}{ Total Skor } \\
\cline { 2 - 7 } & SS & ST & S & TS & STS & \\
\hline 1 & 18 & 34 & 17 & 3 & 8 & 291 \\
\hline 2 & 18 & 36 & 13 & 5 & 8 & 291 \\
\hline 3 & 21 & 39 & 9 & 3 & 8 & 302 \\
\hline 4 & 19 & 42 & 8 & 8 & 3 & 306 \\
\hline 5 & 23 & 38 & 7 & 9 & 3 & 309 \\
\hline 6 & 21 & 36 & 10 & 7 & 6 & 299 \\
\hline \multicolumn{7}{|c|}{ Total } \\
\hline
\end{tabular}

Sumber : Hasil Pengolahan Data 2020

Dari tabel 5 di atas dapat

diketahui bahwa nilai reliabilitas

Analisis Deskriptif Data Penelitian

pernyataan pada kuesioner andal untuk

Mencari rentang score dengan mengukur variabelnya.

cara skor maksimum dibagi jumlah

katagori yang ditetapkan dengan rumus sebagai

berikut:

Rentang Skor Kategori $=\frac{\text { Skor Maksimum }- \text { Skor Minimum }}{5}$

\section{Variabel Reliability $\left(\mathbf{X}_{1}\right)$}

Berdasarkan hasil data dilapangan

di dapat sebanyak 88 responden menjawab factor reliability dengan jawaban "Setuju"

Pada tabel 5, diperoleh total skor sebesar 1798 dengan bobot skor tertinggi 5 dan bobot skor terendah 1 untuk pernyataan variabel reliability. Di bawah ini merupakan perhitungan rentang tingkat skor untuk membuat interval kategori variabel reliability.
Skor maksimum $=88 \times 6 \times 5=2400$

Skor minimum $=88 \times 6 \times 1=480$

Rentang skor $=2400-480=1920$

Rentang antar tingkat $\quad=1920 / 5=384$

Berdasarkan perhitungan di atas, didapatkan panjang interval untuk setiap kategori adalah 384 sehingga dari jumlah skor tanggapan responden atas 6 butir pernyataan mengenai reliability jika digambarkan dalam garis kontinum maka akan diperoleh rentang sebagai berikut: 
Gambar 1

Garis Kontinum Variabel Reliability

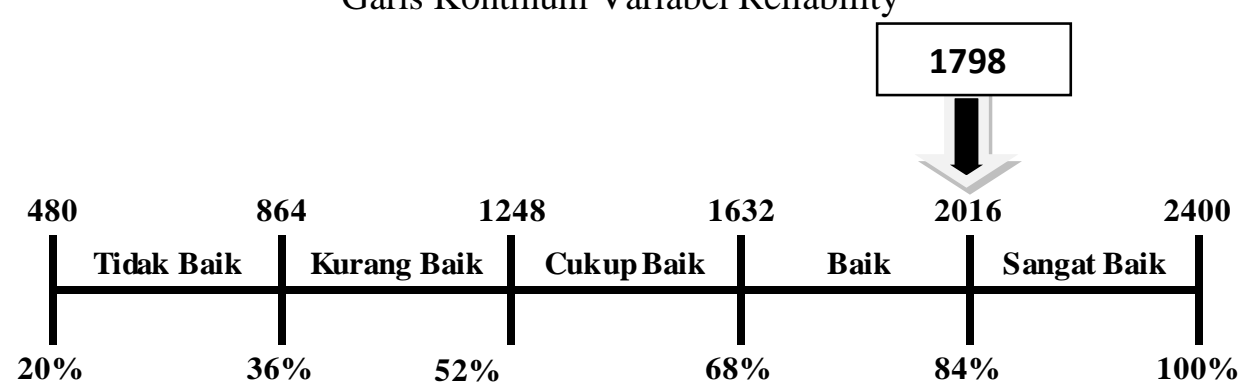

Sumber : Hasil Pengolahan Data 2020

Berdasarkan garis kontinum di atas melalui jumlah skor tanggapan dari 6 pernyataan yang diajukan mengenai variabel reliability, maka dapat diketahui bahwa tanggapan responden mengenai reliability termasuk dalam kategori "Baik".

\section{Variabel Responsiveness $\left(\mathrm{X}_{2}\right)$}

Hasil data lapangan yang diperoleh menunjukan sebagian besar menjawab "Setuju" terhadap pernyataan-pernyataan tentang responsiveness. Dari 80 responden yang mengembalikan kuesioner diperoleh jawaban mengenai responsiveness pada tabel 7

Tabel 7

Skor Jawaban Responden Terhadap Item-item Pernyataan Pada Variabel

\begin{tabular}{|c|c|c|c|c|c|c|}
\hline \multirow{2}{*}{ No. } & \multicolumn{7}{|c|}{ Jawaban Responden } & Total \\
\cline { 2 - 6 } & SS & ST & S & TS & STS & Skor \\
\hline 1 & 14 & 43 & 10 & 6 & 7 & 291 \\
\hline 2 & 16 & 40 & 11 & 6 & 7 & 292 \\
\hline 3 & 17 & 40 & 10 & 6 & 7 & 294 \\
\hline 4 & 10 & 48 & 9 & 6 & 7 & 288 \\
\hline \multicolumn{7}{|c|}{ Total } \\
\hline
\end{tabular}

Sumber : Hasil Pengolahan Data 2020

Gambar 2

Garis Kontinum Variabel Responsiveness

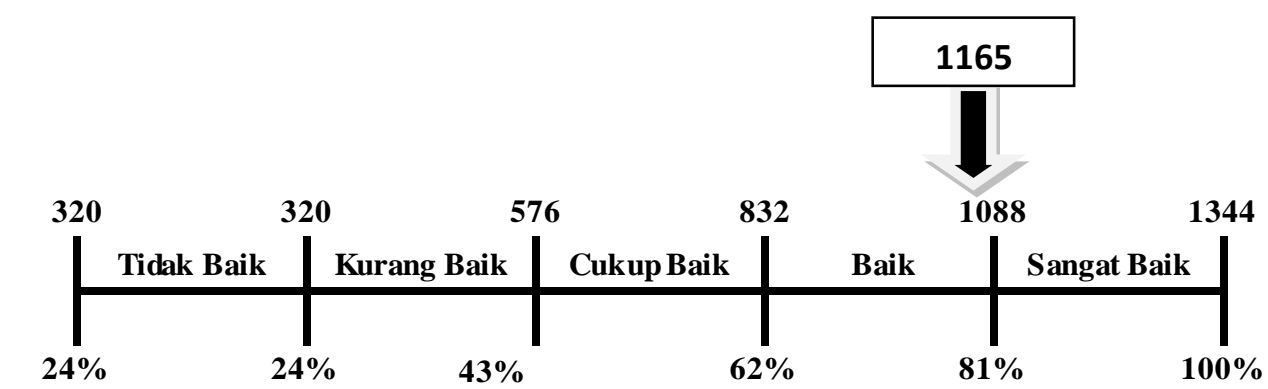

Sumber : Hasil Pengolahan Data 2020 
Berdasarkan hasil olah pada tabel 7, diperoleh total skor sebesar 578 dengan bobot skor tertinggi 5 dan bobot skor terendah 1 untuk pernyataan variabel responsiveness. Di bawah ini merupakan perhitungan rentang tingkat skor untuk membuat interval kategori variabel responsiveness.

Skor maksimum $=80 \times 4 \times 5=1600$

Skor minimum $=80 \times 4 \times 1=320$

Rentang skor $=1600-320=1280$

Rentang antar tingkat $=1280 / 5=256$

Berdasarkan perhitungan di atas, didapatkan panjang interval untuk setiap kategori adalah 256 sehingga dari jumlah skor tanggapan responden atas 4 butir pernyataan mengenai responsiveness jika digambarkan dalam garis kontinum maka akan diperoleh rentang sebagaimana digambarkan pada gambar 2.

Berdasarkan garis kontinum di atas melalui jumlah skor tanggapan dari 4 pernyataan yang diajukan mengenai variabel responsiveness, maka dapat diketahui bahwa tanggapan responden mengenai responsiveness termasuk dalam kategori "Sangat Baik".

\section{Variabel Emphaty $\left(\mathbf{X}_{3}\right)$}

Hasil data lapangan yang diperoleh menunjukkan sebagian besar menjawab "Setuju" terhadap pernyataan-pernyataan tentang emphaty, sebagaimana pada tabel 8 .

Berdasarkan hasil olah tabel pada tabel 8 , diperoleh total skor sebesar 870 dengan bobot skor tertinggi 5 dan bobot skor terendah 1 untuk pernyataan variabel emphaty. Di bawah ini merupakan perhitungan rentang tingkat skor untuk membuat interval kategori variabel emphaty:

Skor maksimum $=88 \times 3 \times 5=1200$

Skor minimum $=88 \times 3 \times 1=240$

Rentang skor $=1200-240=960$

Rentang antar tingkat $=960 / 5=192$

Berdasarkan perhitungan di atas, didapatkan panjang interval untuk setiap kategori adalah 192 sehingga dari jumlah skor tanggapan responden atas 3 butir pernyataan mengenai emphaty jika digambarkan dalam garis kontinum maka akan diperoleh rentang sesuai gambar 3 .

Tabel 8

Skor Jawaban Responden Terhadap Item-item

Pernyataan Pada Variabel

\begin{tabular}{|c|c|c|c|c|c|c|}
\hline \multirow{2}{*}{ No. } & \multicolumn{7}{|c|}{ Jawaban Responden } & \multirow{2}{*}{ Total Skor } \\
\cline { 2 - 6 } & SS & ST & S & TS & STS & \\
\hline 1 & 18 & 35 & 11 & 8 & 8 & 287 \\
\hline 2 & 14 & 40 & 11 & 7 & 8 & 285 \\
\hline 3 & 19 & 37 & 11 & 9 & 4 & 298 \\
\hline \multicolumn{7}{|c|}{ Total } \\
\hline
\end{tabular}

Sumber : Hasil Pengolahan Data 2020

PERFORMANCE : Jurnal Bisnis \& Akuntansi Volume 11, No.2 September 2021 
Gambar 3

Kontinum Variabel Emphaty

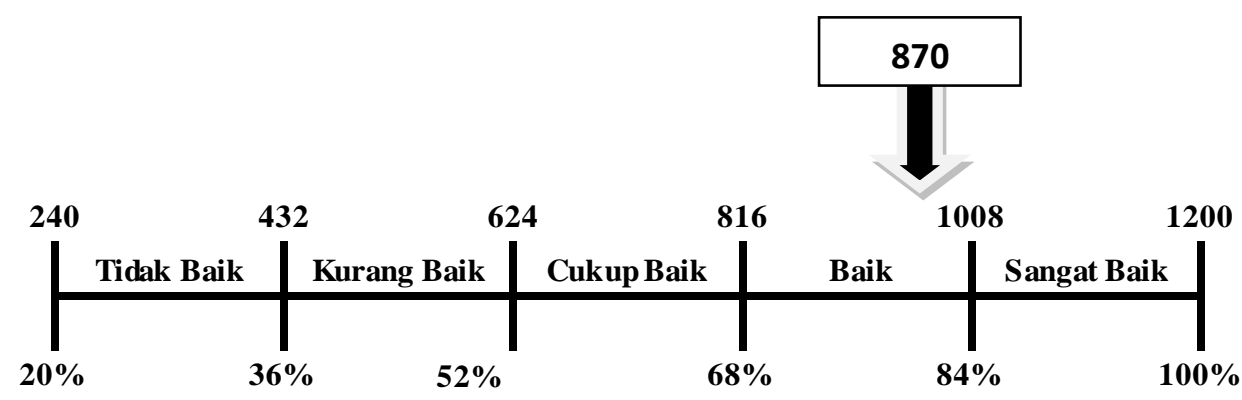

Sumber : Hasil Pengolahan Data 2020

Berdasarkan garis kontinum di atas melalui jumlah skor tanggapan dari 3 pernyataan yang diajukan mengenai variabel emphaty, maka dapat diketahui bahwa tanggapan responden mengenai emphaty termasuk dalam kategori "Baik".

\section{Variabel Kepuasan Konsumen (Y)}

Berdasarkan hasil data 88 responden menjawab "Setuju"

Berdasarkan hasil olah tabel pada tabel 9, diperoleh total skor sebesar 2366 dengan bobot skor tertinggi 5 dan bobot skor terendah 1 untuk pernyataan variabel kepuasan konsumen.

Di bawah ini merupakan perhitungan rentang tingkat skor untuk membuat interval kategori variabel kepuasan konsumen, sebagai berikut :

Skor maksimum $=88 \times 8 \times 5=3200$

Skor minimum $=88 \times 8 \times 1=640$

Rentang skor $=3200-640=2560$

Rentang antar tingkat $=2560 / 5=512$

Berdasarkan perhitungan di atas, didapatkan panjang interval untuk setiap kategori adalah 512 sehingga dari jumlah skor tanggapan responden atas 8 butir pernyataan mengenai kepuasan konsumen jika digambarkan dalam garis kontinum maka akan diperoleh rentang sesuai gambar 4 .

Tabel 9

Skor Jawaban Responden Terhadap Item-item Pernyataan Pada Variabel

\begin{tabular}{|c|c|c|c|c|c|c|}
\hline \multirow{2}{*}{ No. } & \multicolumn{7}{|c|}{ Jawaban Responden } & \multirow{2}{*}{ Total Skor } \\
\cline { 2 - 7 } & SS & S & KS & TS & STS & \\
\hline 1 & 22 & 37 & 5 & 11 & 5 & 300 \\
\hline 2 & 25 & 35 & 4 & 11 & 5 & 304 \\
\hline 3 & 21 & 37 & 7 & 7 & 8 & 296 \\
\hline 4 & 21 & 30 & 15 & 6 & 8 & 290 \\
\hline 5 & 19 & 40 & 11 & 5 & 5 & 303 \\
\hline 6 & 26 & 34 & 7 & 10 & 3 & 310 \\
\hline 7 & 16 & 35 & 10 & 16 & 3 & 285 \\
\hline 8 & 13 & 38 & 7 & 18 & 4 & 278 \\
\hline \multicolumn{7}{|c|}{ Total } \\
\hline
\end{tabular}

Sumber : Hasil Pengolahan Data 2020 
Gambar 4

Kontinum Variabel Kepuasan Konsumen

2366

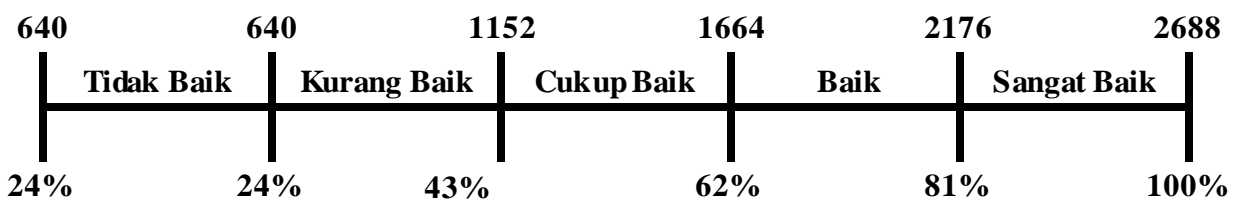

Sumber : Hasil Pengolahan Data 2020

Berdasarkan garis kontinum di Heteroskedastisitas, dan Uji atas melalui jumlah skor tanggapan dari Multikolinearitas.

8 pernyataan yang diajukan mengenai Uji Normalitas

variabel kepuasan konsumen, maka Berdasarkan Tabel 10 dibawah dapat diketahui bahwa tanggapan responden diketahui bahwa nilai signifikansi mengenai kepuasan konsumen dalam Asymp. Sig. (2-tailed) atau probabilitas kategori "Sangat Baik".

sebesar 0.200 dan lebih besar dari 0.05

\section{Uji Asumsi Klasik}

Pengujian asumsi ini terdiri atas tiga maka dapat disimpulkan bahwa data yang digunakan telah memenuhi asumsi pengujian, yakni Uji Normalitas, Uji normalitas.

Tabel 10

Uji Normalitas

One-Sample Kolmogorov-Smirnov Test

\begin{tabular}{|c|c|}
\hline & Unstandardized Residual \\
\hline $\mathrm{N}$ & 80 \\
\hline Normal Mean &, 0000000 \\
\hline $\begin{array}{l}\text { Parame Std. Deviation } \\
\text { ters } \mathrm{a}^{\mathrm{a}, \mathrm{b}}\end{array}$ & 5,22767037 \\
\hline Most Absolute & ,079 \\
\hline Extrem Positive & ,079 \\
\hline e $\quad$ Negative & \\
\hline $\begin{array}{l}\text { Differe } \\
\text { nces }\end{array}$ &,- 064 \\
\hline Test Statistic & 079 \\
\hline Asymp. Sig. (2-tailed) & $200^{\mathrm{c}, \mathrm{d}}$ \\
\hline
\end{tabular}

a. Test distribution is Normal.

Sumber : Hasil Pengolahan Data 2020 
Gambar 5

Grafik Normalitas Data

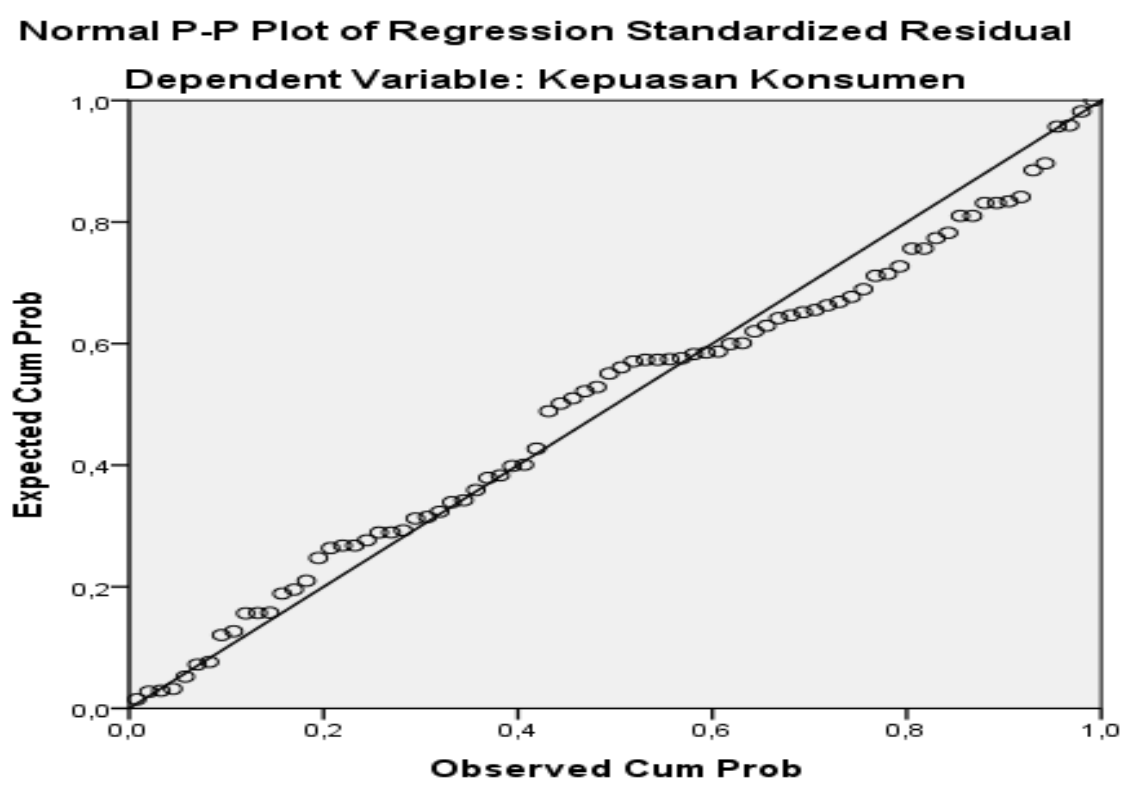

Sumber : Hasil Pengolahan Data 2020

\section{Uji Heteroskedastisitas}

Uji heteroskedastisitas aplikasi program

SPSS 23.0 for Windows, Berdasarkan pola yang ada tidak terdapat gejala heteroskedastisitas

Gambar 6

Scatterplot Uji Heteroskedastisitas

Scatterplot

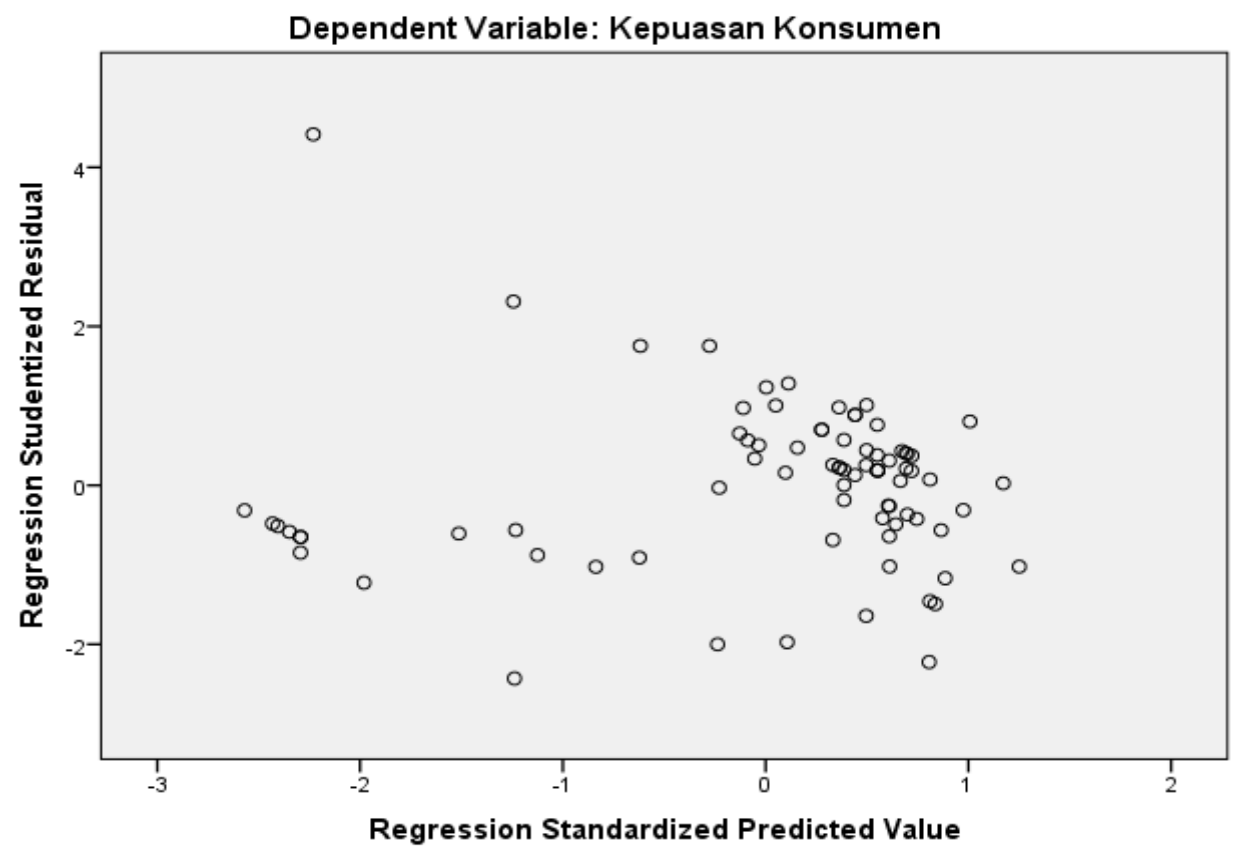

Sumber : Hasil Pengolahan Data 2020

PERFORMANCE : Jurnal Bisnis \& Akuntansi Volume 11, No.2 September 2021 
Tabel 11

Uji Multikolinearitas

Coefficients $^{\mathbf{a}}$

\begin{tabular}{|ll|l|l|}
\hline \multirow{2}{*}{ Model } & \multicolumn{2}{|l|}{ Collinearity Statistics } \\
\cline { 3 - 4 } & Tolerance & VIF \\
\hline 1 & Reliability &, 356 & 2,811 \\
& Responsiveness &, 338 & 2,962 \\
& Emphaty &, 319 & 3,137 \\
\hline
\end{tabular}

a. Dependent Variable: Kepuasan Konsumen

Sumber : Hasil Pengolahan Data 2020

Tabel 12

Hasil Koefisien Regresi

Coefficients $^{\mathrm{a}}$

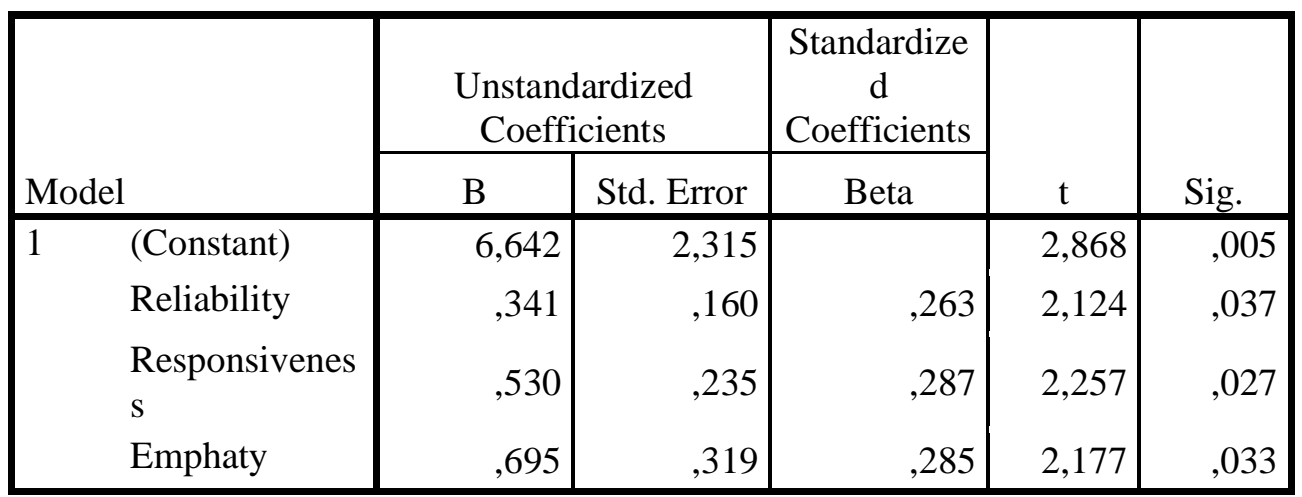

a. Dependent Variable: Kepuasan Konsumen

Sumber : Hasil Pengolahan Data 2020

\section{Uji Multikolinearitas}

Dengan menggunakan program SPSS

23.0 for Windows, didapat outputnilai

VIF untuk masing-masing variabel

bebas dirunjukkan pada tabel 11. Hasil

di atas menunjukkan bahwa tidak terdapat multikolinearitas antar variabel bebas dalam model regresi.

\section{Analisis Pengujian Hipotesis}

Analisis regresi linear berganda digunakan untuk mengetahui besarnya pengaruh yang meliputi: Reliability, responsiveness dan emphaty terhadap kepuasan konsumen.

\section{Analisis Persamaan Regresi Linear Berganda}

Dari hasil output SPSS pada tabel 12, maka dapat diketahui bahwa nilai kontstanta dan koefisien regresi sehingga dapat dibentuk persamaan Regresi Linear Berganda sebagai berikut:

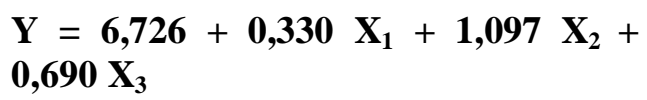$$
Y=6,726+0,330 X_{1}+1,097 X_{2}+
$$
$0,690 \mathrm{X}_{3}$ 
FAKULTAS EKONOMI DAN BISNIS UNIVERSITAS WIRARAJA - MADURA

Pengujian Hipotesis Parsial (Uji-t)

Hasil Uji Parcial ditunjukkan pada tabel

13.

\section{Pengujian hipotesis variabel $\mathbf{X}_{1}$ (Reliability)}

Tingkat signifikan $(\alpha)$ sebesar $5 \%$, dan derajat kebebasan $(\mathrm{v})=76(\mathrm{n}-(\mathrm{k}+1)$ didapat nilai $t_{\text {tabel }}$ 1,992. Dari hasil perhitungan tersebut atau pada hasil output SPSS, maka dapat dibuat gambar sebagaimana gambar 7 .

Tabel 13

Pengujian Hipotesis Parsial

Coefficients $^{\mathrm{a}}$

\begin{tabular}{|c|c|c|c|c|c|c|}
\hline \multirow{2}{*}{\multicolumn{2}{|c|}{ Model }} & \multicolumn{2}{|c|}{$\begin{array}{c}\text { Unstandardized } \\
\text { Coefficients }\end{array}$} & \multirow{2}{*}{$\begin{array}{c}\text { Standardized } \\
\text { Coefficients } \\
\text { Beta } \\
\end{array}$} & \multirow[b]{2}{*}{ } & \multirow[b]{2}{*}{ Sig. } \\
\hline & & B & Std. Error & & & \\
\hline 1 & (Constant) & 6,642 & 2,315 & & 2,868 &, 005 \\
\hline & Reliability &, 341 & , 160 & ,263 & 2,124 & ,037 \\
\hline & $\begin{array}{l}\text { Responsivenes } \\
\mathrm{S}\end{array}$ &, 530 & ,235 & ,287 & 2,257 & ,027 \\
\hline & Emphaty & ,695 & ,319 & ,285 & 2,177 & 033 \\
\hline
\end{tabular}

a. Dependent Variable: Kepuasan Konsumen

Sumber : Hasil Pengolahan Data 2020

Gambar 7

Kurva Uji Hipotesis Parsial Variabel X1 Terhadap Y

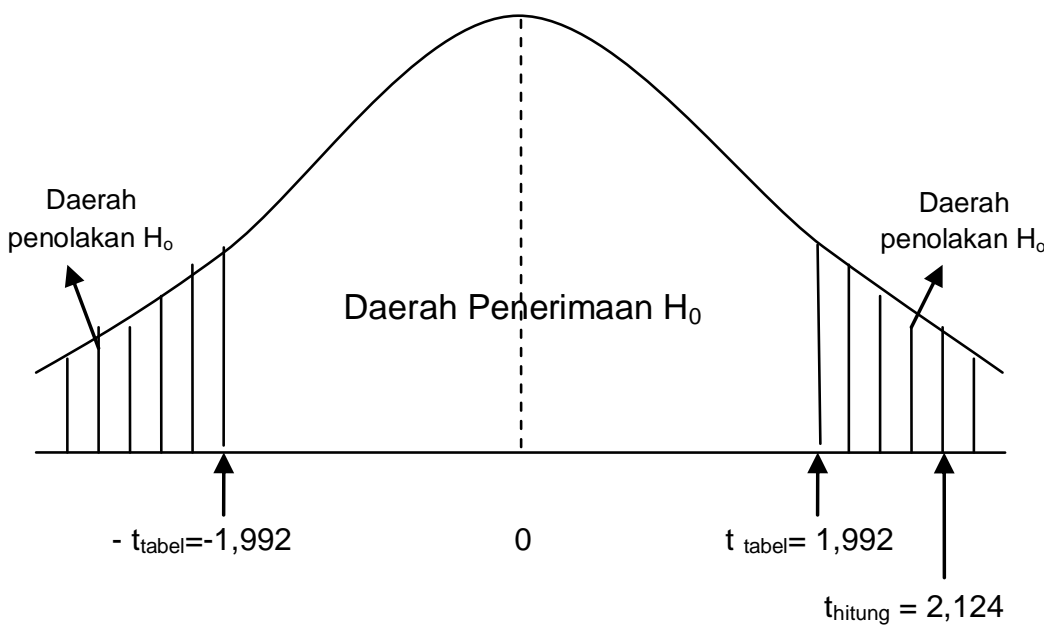

Sumber : Hasil Pengolahan Data 2020 


\section{FAKULTAS EKONOMI DAN BISNIS UNIVERSITAS WIRARAJA - MADURA}

Dari output SPSS diatas diperoleh nilai thitung untuk X1 sebesar 2,017 dan ttabel 1,989 dan nilai p-value (sig.) 0,047. Dikarenakan nilai thitung $>$ ttabel dan nilai $\mathrm{p}$-value (sig.) $<(\alpha=0.05)$, maka H0 ditolak dan $\mathrm{H} 1$ diterima, artinya reliability berpengaruh positif dan signifikan terhadap kepuasan konsumen.

Pengujian hipotesis variabel $\mathbf{X}_{2}$ (Responsiveness)

Tingkat signifikan $(\alpha)$ sebesar 5\%, dan derajat kebebasan $(\mathrm{v})=76(\mathrm{n}-(\mathrm{k}+1)$ didapat nilai $t_{\text {tabel }}$ 1,992. Dari hasil perhitungan tersebut atau pada hasil output SPSS, maka dapat dibuat gambar sebagaimana gambar 8 .

Dari output SPSS diperoleh nilai $\mathrm{t}_{\text {hitung }}$ untuk $\mathrm{X}_{2}$ sebesar 2,257 dan $\mathrm{t}_{\text {tabel }}$ 1,992 dan nilai p-value (sig.) 0,027. Dikarenakan nilai $t_{\text {hitung }}>t_{\text {tabel }}$ dan nilai p-value $($ sig. $)<(\alpha=0.05)$, maka $\mathrm{H}_{0}$ ditolak dan $\mathrm{H}_{1}$ diterima, artinya responsiveness berpengaruh positif dan signifikan terhadap kepuasan konsumen.

Pengujian hipotesis variabel $\mathbf{X}_{3}$ (Emphaty)

Tingkat signifikan $(\alpha)$ sebesar 5\%, dan derajat kebebasan $(\mathrm{v})=76(\mathrm{n}-(\mathrm{k}+1)$ didapat nilai $t_{\text {tabel }}$ 1,992. Dari hasil perhitungan tersebut atau pada hasil output SPSS, maka dapat dibuat gambar sebagaimana gambar 9 .

Dari output SPSS diperoleh nilai $\mathrm{t}_{\text {hitung }}$ untuk $\mathrm{X}_{3}$ sebesar 2,177 dan $\mathrm{t}_{\text {tabel }}$ 1,992 dan nilai p-value (sig.) 0,033. Dikarenakan nilai $t_{\text {hitung }}<\mathrm{t}_{\text {tabel }}$ dan nilai p-value (sig.) $>(\alpha=0.05)$, maka $\mathrm{H}_{0}$ ditolak dan $\mathrm{H}_{1}$ diterima, artinya Emphaty berpengaruh positif dan signifikan terhadap kepuasan konsumen.

Gambar 8

Kurva Uji Hipotesis Parsial Variabel X2 Terhadap Y

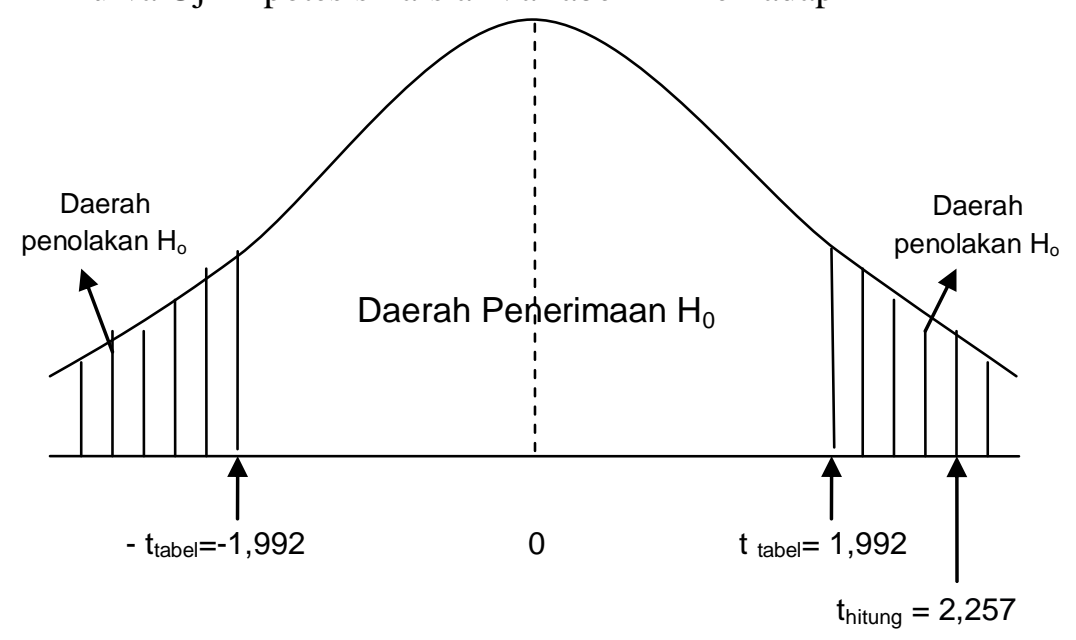

Sumber : Hasil Pengolahan Data 2020 
Gambar 9

Kurva Uji Hipotesis Parsial Variabel X3 Terhadap Y

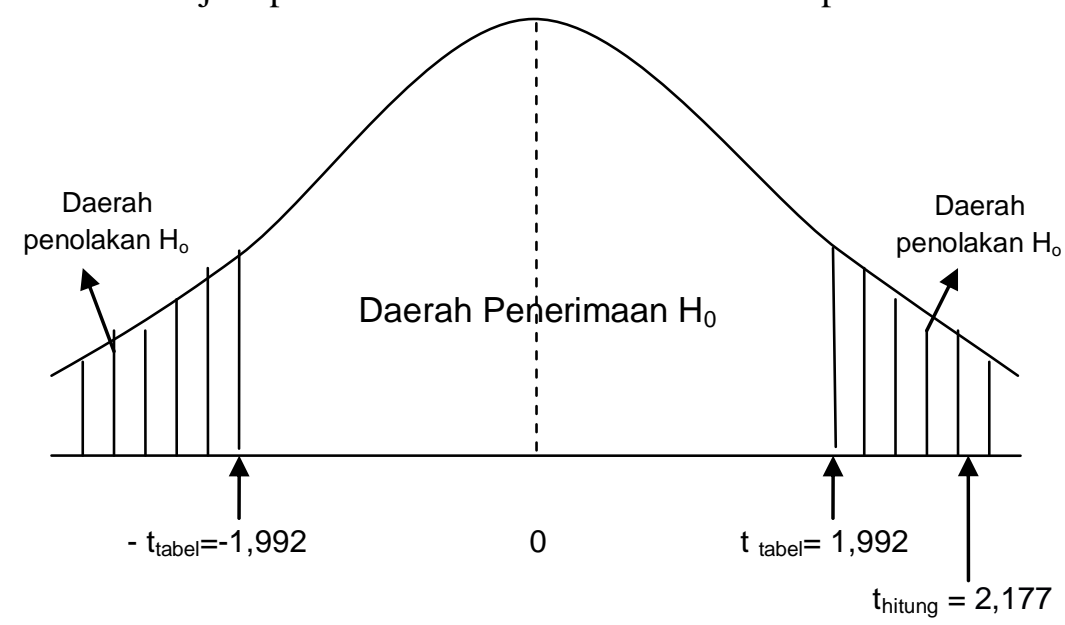

Sumber : Hasil Pengolahan Data 2020

\section{Pengujian Hipotesis Simultan (Uji-F)}

Tingkat signifikan $(\alpha)$ sebesar $5 \%$ dengan menggunakan program SPSS diperoleh output sebagaimana tabel 14.

Berdasarkan output diketahui nilai $\mathrm{F}_{\text {hitung }}$ sebesar 35,890 dengan p-value (sig) 0,000 . Dengan $\alpha=0.05$ serta derajat kebebasan $\mathrm{v}_{1}=76(\mathrm{n}-(\mathrm{k}+1))$ dan $\mathrm{v}_{2}=3$ maka di dapat $\mathrm{F}_{\text {tabel }} 2,725$. Dikarenakan nilai $\mathrm{F}_{\text {hitung }}>\mathrm{F}_{\text {tabel }}(35,890>2,725)$ maka dapat disimpulkan $\mathrm{H}_{0}$ ditolak, artinya variabel reliability, responsiveness dan emphaty secara bersama-sama berpengaruh signifikan terhadap kepuasan konsumen.

Tabel 14

Pengujian Hipotesis Simultan

ANOVA $^{\mathrm{a}}$

\begin{tabular}{|ll|r|r|r|r|r|}
\hline \multicolumn{2}{|l|}{ Model } & \multicolumn{1}{|c|}{$\begin{array}{c}\text { Sum of } \\
\text { Squares }\end{array}$} & Df & Mean Square & F & Sig. \\
\hline 1 & Regression & 3058,596 & 3 & 1019,532 & 35,890 &, $000^{\mathrm{b}}$ \\
& Residual & 2158,954 & 76 & 28,407 & & \\
& Total & 5217,550 & 79 & & & \\
\hline
\end{tabular}

a. Dependent Variable: Kepuasan Konsumen

b. Predictors: (Constant), Emphaty, Reliability, Responsiveness

Sumber : Hasil Pengolahan Data 2020 
Tabel 15

Hasil Koefisien Determinasi

Model Summary ${ }^{\text {b }}$

\begin{tabular}{|l|c|r|r|r|}
\hline Model & $\mathrm{R}$ & $\mathrm{R}$ Square & \multicolumn{1}{c|}{$\begin{array}{c}\text { Adjusted R } \\
\text { Square }\end{array}$} & \multicolumn{2}{c|}{$\begin{array}{c}\text { Std. Error of the } \\
\text { Estimate }\end{array}$} \\
\hline 1 & $\begin{array}{r}766 \\
\mathrm{a}\end{array}$ &, 586 &, 570 & 5,32985 \\
\hline
\end{tabular}

a. Predictors: (Constant), Emphaty, Reliability, Responsiveness

b. Dependent Variable: Kepuasan Konsumen

Sumber : Hasil Pengolahan Data 2020

$$
\begin{aligned}
\mathrm{KD} & =\mathrm{R}^{2} \times 100 \% \\
& =(0,766)^{2} \times 100 \% \\
& =58,6 \%
\end{aligned}
$$

\section{Analisis Koefisien Determinasi $\left(\mathbf{R}^{2}\right)$}

Setelah diketahui nilai $\mathrm{R}$ (Korelasi)

sebesar 0.766, maka koefisien determinasi dapat dihitung menggunakan rumus sebagaimana tabel 15.

Berdasrkan hasil uji nilai $\mathrm{KD}$ sebesar 58,6\% yang menunjukkan arti bahwa variabel reliability, responsiveness dan emphaty memberikan pengaruh simultan (bersama-sama) sebesar 58,6\% terhadap kepuasan konsumen (Y). Sedangkan sisanya sebesar $41,4 \%$ dipengaruhi oleh faktor lain yang diabaikan penulis.

\section{KESIMPULAN DAN SARAN}

\section{Kesimpulan}

1. Berdasarkan hasil uji parsial bahwa pengaruh variabel Reliability, Responsiveness dan Emphaty terhadap kepuasan konsumen pada Mall Pelayanan Publik di Kabupaten Sumenep berpengaruh positif dan signifikan.
2. Berdasarkan hasil uji simultan yang dilakukan berpengaruh yang signifikan dari Reliability, Responsiveness dan Emphaty terhadap kepuasan konsumen secara simultan pada Mall Pelayanan Publik di Kabupaten Sumenep.

\section{Saran}

1. Perlu adanya papan digital nomor antrian, hal tersebut untuk memudahkan masyarakat pelanggan Mall Pelayanan Publik mengetahui posisi dirinya alam pelayanan.

2. Gedung yang digunakan kurang mencakup jumlah perusahaan yang ada di dalamnya, sehingga pada hari tertentu banyak konsumen yang masih kekurangan tempat duduk di ruang tunggu di masa pandemi covid 19 


\section{DAFTAR PUSTAKA}

Apriyani, D. A., \& Sunarti, S. (2017). Pengaruh Kualitas Pelayanan Terhadap Kepuasan Konsumen (Survei Pada Konsumen the Little a Coffee Shop Sidoarjo). Jurnal Administrasi Bisnis, 51(2), 1-7.

Kotler, Philip \& Keller, Kevin Lane. 2009. Manajemen Pemasaran. Jilid 1, Edisi Ketiga Belas. Erlangga.

Kotler, Philip \& Keller, Kevin Lane. 2009. Manajemen Pemasaran. Jilid 2, Edisi Ketiga Belas. Erlangga.

Rahman, A., Yuniarti, P., \& Aprilia, D. (2020). PENGARUH KUALITAS PELAYANAN TERHADAP KEPUASAN KONSUMEN PADA PT SETYA KULINER MANDIRI JAGAKARSA JAKARTA SELATAN. JITK (Jurnal Ilmu Pengetahuan Dan Teknologi Komputer), 5(2), 191-196.

Rizqy, R. R., Warso, \& Fathoni, A. (2016). PENGARUH KUALITAS PELAYANAN
TERHADAP KEPUASAN

KONSUMEN (Studi Kasus pada Konsumen PT. Graha Service Indonesia Cabang Semarang). Journal of Management, 2(2).

Sugiono. 2018. Metode Penelitian. Bandung: Alfabeta.

Tjiptono, Fandy. 2015. Strategi Pemasaran. Yogyakarta: Andi.

Utomo, S. B., \& Riswanto, I. (2019). Pengaruh Kualitas Pelayanan Terhadap Kepuasan Konsumen Pada Bengkel Ahass Gumilang Motor Rajagaluh Kabupaten Majalengka. Syntax, 1(6).

Winardi, Sirajuddin, dan Sukriono, Didik. 2012. Hukum Pelayanan Publik. Malang: Setara Press (Kelompok Intrans Publishing).

Yulianto, H., \& Yahya, S. D. (2018, October). Pengaruh Dimensi Kualitas Layanan Publik Terhadap Kepuasan Masyarakat Pengguna Trans Mamminasata. In Prosiding Seminar Nasional: Manajemen, Akuntansi, dan Perbankan (Vol. 1, No. 1, pp. 1234-1251). 